\title{
Mesangioproliferative Glomerulonephritis in Mink with Encephalitozoonosis
}

\author{
By Z.-y. Zhou and K. Nordstoga
}

Department of Pathology, Norwegian College of Veterinary Medicine, Oslo, Norway.

\begin{abstract}
Zhou Z.-y. and K. Nordstoga: Mesangioproliferative glomerulonephritis in mink with encephalitozoonosis. Acta vet. scand. 1993, 34, 69-76. - Renal specimens from 6 mink with encephalitozoonosis were studied by light and electron microscopy and immunohistochemistry. The glomeruli of affected kidneys had a mesangioproliferative glomerulonephritis which was characterized by an increase in mesangial cells and matrix in most glomeruli. Some glomeruli were partially or completely sclerosed. There were protein or granular casts in the cortical and medullary tubules. Interstitial nephritis, vasculitis and tubular cysts were found. Electron microscopy demonstrated extensive matrix and increased cellularity in the mesangial areas. Glomeruli showed segmentally thickened or wrinkled capillary basement membranes. Electron dense deposits were found in the glomerular basement membranes and mesangium. Peroxidase-anti-peroxidase immunohistochemistry demonstrated that IgG and IgM positive material was present as granular deposits in the glomerular basement membrane and occasionally in the mesangium.
\end{abstract}

light and electron microscopy; immunohistochemistry.

\section{Introduction}

Encephalitozoon cuniculi is an obligate intracellular protozoan parasite known to infect a wide variety of animals and man. Although systemic infection occurs, the kidney is the organ most commonly affected (Bjerkås et al. 1988, McCully et al. 1978, Plowright 1952, Shadduck \& Pakes 1971, Testoni 1974, Van Rensburg \& Du Plessis 1971, Wilson 1979). Many studies have revealed that the disease may give rise to marked interstitial nephritis (Bjerkås et al. 1988, Botha et al. 1986, McCully et al. 1978, Nordstoga 1972, Sanford 1987, Zhou et al. 1992), while glomerulonephritis in association with encephalitozoonosis has only been reported in dogs (McCully et al. 1978).

Glomerulonephritis has been increasingly recognized in recent years as an important cause of renal disease in domestic animals. Mesangio- proliferative glomerulonephritis is encountered in man and animals including cats, dogs, sheep, cattle, horses and pigs (Dore et al. 1987, Jansen 1988, Kincaid-Smith 1975, McCausland \& Milestone 1976, Shirota et al. 1986, Slauson et al. 1971, Slauson \& Lewis 1979). In mink mesangial and sclerosing glomerulonephritis has been described in association with Aleutian disease (Müller-Peddinghaus et al. 1980a b, Portis \& Coe 1979, Slauson \& Lewis 1979).

This paper describes histological, ultrastructural and immunohistological characteristics of mesangioproliferative glomerulonephritis in mink suffering from encephalitozoonosis. Extra-glomerular lesions in the same animals have been reported in a separate paper (Zhou et al. 1992). 


\section{Materials and methods Animals}

The renal tissue from 6 mink with encephalitozoonosis was studied. All animals exhibited extraglomerular renal changes typical for encephalitozoonosis (Zhou et al. 1992) and were free from Aleutian disease, as judged by the counterimmunoelectrophoresis ("agar") test (Cho \& Greenfield 1978). The etiological diagnosis was based on the india ink test (Waller 1977), and on the demonstration of the parasites in the cataractous lens (Bjerkås 1990). Renal tissue from 2 normal mink was used as controls.

\section{Light Microscopy}

Pieces of the kidneys were fixed in a $4 \%$ phosphate buffered solution of formaldehyde and embedded in paraffin. The sections were cut at $4 \mu \mathrm{m}$ and stained with haematoxilin and eosin (HE), elastin van Gieson (EVG), periodic acidSchiff (PAS), periodic acid-methenamine-silver and Martius scarlet blue.

\section{Electron Microscopy}

Only paraffin - embedded renal tissue was available; the specimens were deparaffinized and post-fixed in $2 \%$ osmium tetroxide solution, dehydrated in a graded ethanol series and embedded in Epon 812. Semithin sections (0,5 $-1 \mu \mathrm{m}$ thick) were stained with toluidine blue for light microscopy.Ultrathin sections (80 $100 \mathrm{~nm}$ ) were stained with uranyl acetate and lead citrate and photographed in a Jeol 100 S electron microscope.

\section{Immunohistochemistry}

The peroxidase-antiperoxidase (PAP) method was applied on formalin-fixed, paraffin embedded renal tissue for detection of $\operatorname{IgA}$, IgG and IgM deposits. Endogenous peroxidase was inhibited by $3 \%$ hydrogen peroxide in methanol for $20 \mathrm{~min}$. The sections were digested with trypsin before incubating with the pri- mary antibody. Rabbit-anti-mink IgA, IgG and IgM (from the Royal Veterinary and Agricultural University, Copenhagen, Denmark), diluted 1:1000 in tris buffered saline were used as the primary antibodies. Non-immune rabbit serum and kidneys sections from normal mink were used as controls. Anti-rabbit IgG (secondary antibody) and PAP complexes $\left(\right.$ Sigma $\left.^{\mathrm{R}}\right)$ were used. Sections were finally treated with diaminobenzidine hydrochloric acid solution $\left(\operatorname{Sigma}^{\mathrm{R}}\right)$.

\section{Results}

\section{Light Microscopy}

Five of the 6 mink had diffuse glomerular lesions which were either global or segmental. The remaining mink showed focal changes. In

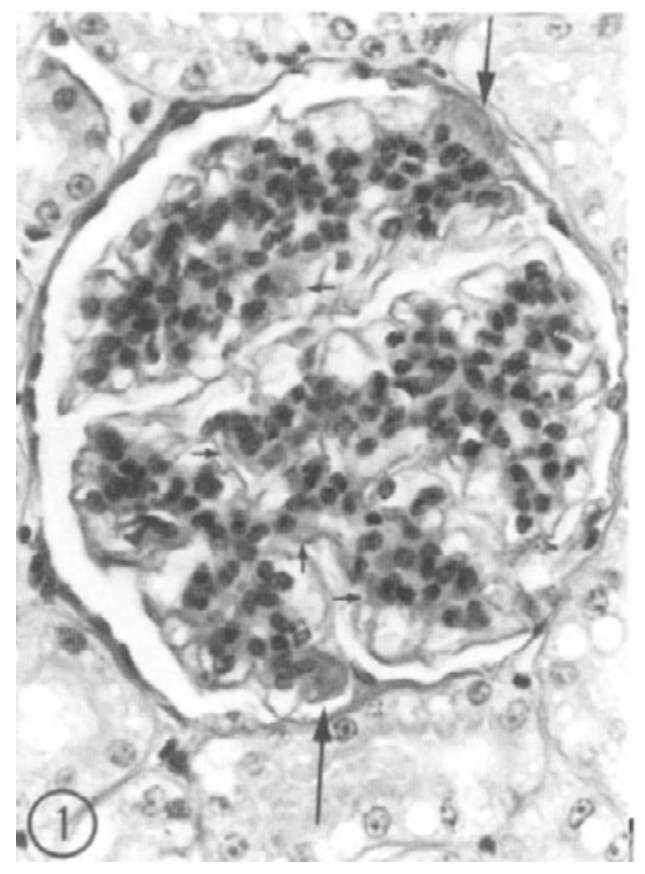

Figure 1. A glomerulus with increased cellularity and abundant PAS-positive material (arrows) in the mesangium. PAS, $\times 300$. 


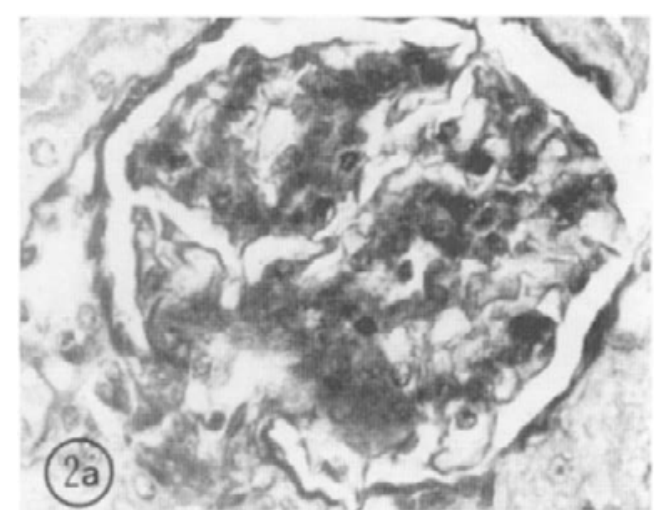

severe cases, global as well as segmental glomerular lesions were present; segmental lesions were sometimes prominent also in moderate cases. The principal features of glomerular alterations were that mesangial regions were greatly expanded and hypercellular, and that the glomerular capillary lumens were either partially or completely obliterated.

Most glomeruli appeared to be enlarged and contained a globally or segmentally increased number of mesangial cells. There was a marked widening of mesangial areas and, less frequently, deposition of PAS-positive material in glomerular basement membrane and paramesangial areas (Fig. 1). The glomerular basement membranes were segmentally thickened and, in some glomeruli, capillaries were collapsed and obliterated. Adhesion of peripheral capillary loops to parietal capsule with PAS-positive material was observed occasionally, and in some glomeruli, proliferation of the parietal epithelial cells or fibrocellular proliferation had led to cresent formation. Some glomeruli showed eccentric distribution of cells caused by extended capsular space which contained a fibrinous material. In addition, partial or complete mesangial sclerosis was present in all cases. The globally sclerotic glomeruli appeared to be decreased in size and the capsules were shrunken and

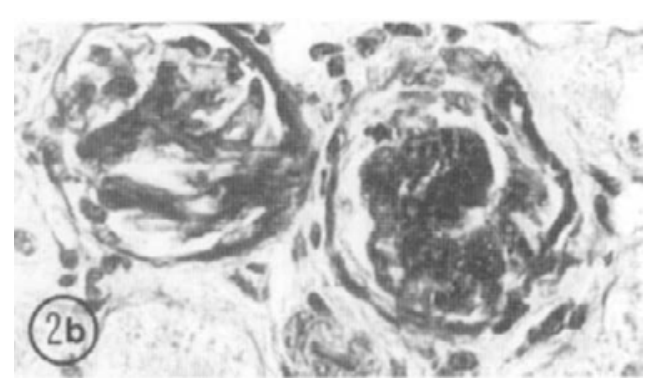

Figure 2. Sclerotic glomeruli. a) The glomerular capillaries are collapsed and obliterated and the parietal capsule is thickened. b) Small glomerular scars. Collapsed, acellular capillary tufts are stained by PAS. $\times 260$.

thickened. The glomerular capillaries were seen as PAS-positive-hypocellular or acellular masses (Fig. 2). In the glomeruli showing segmental lesions, the mesangial sclerosis was mostly present in the juxtaglomerular regions. Sections from control animals appeared unchanged.

\section{Electron microscopy}

Electron microscopic examination revealed that the glomeruli in the affected kidneys had a prominent increase in mesangial cells and matrix. Projections of mesangial cytoplasm often extended into the abundant matrix. Electron dense deposits were found within the mesangial and paramesangial areas of some glomeruli (Figs. 3-4). The basement membranes were thickened segmentally. Usually, thickening of the lamina densa was prominent. Translucent areas were present within the thickened basement membrane (Fig. 5). Fine granular electron dense deposits were observed in both subendothelial and subepithelial sites (Figs. 67). Fusion of foot cell processes was seen in some segments of the affected glomeruli. Some glomeruli showed marked segmental wrinkling of basement membranes. In the globally sclerotic glomeruli seen in the light microscope, the glomeruli were strikingly shrunken, collapsed and replaced 


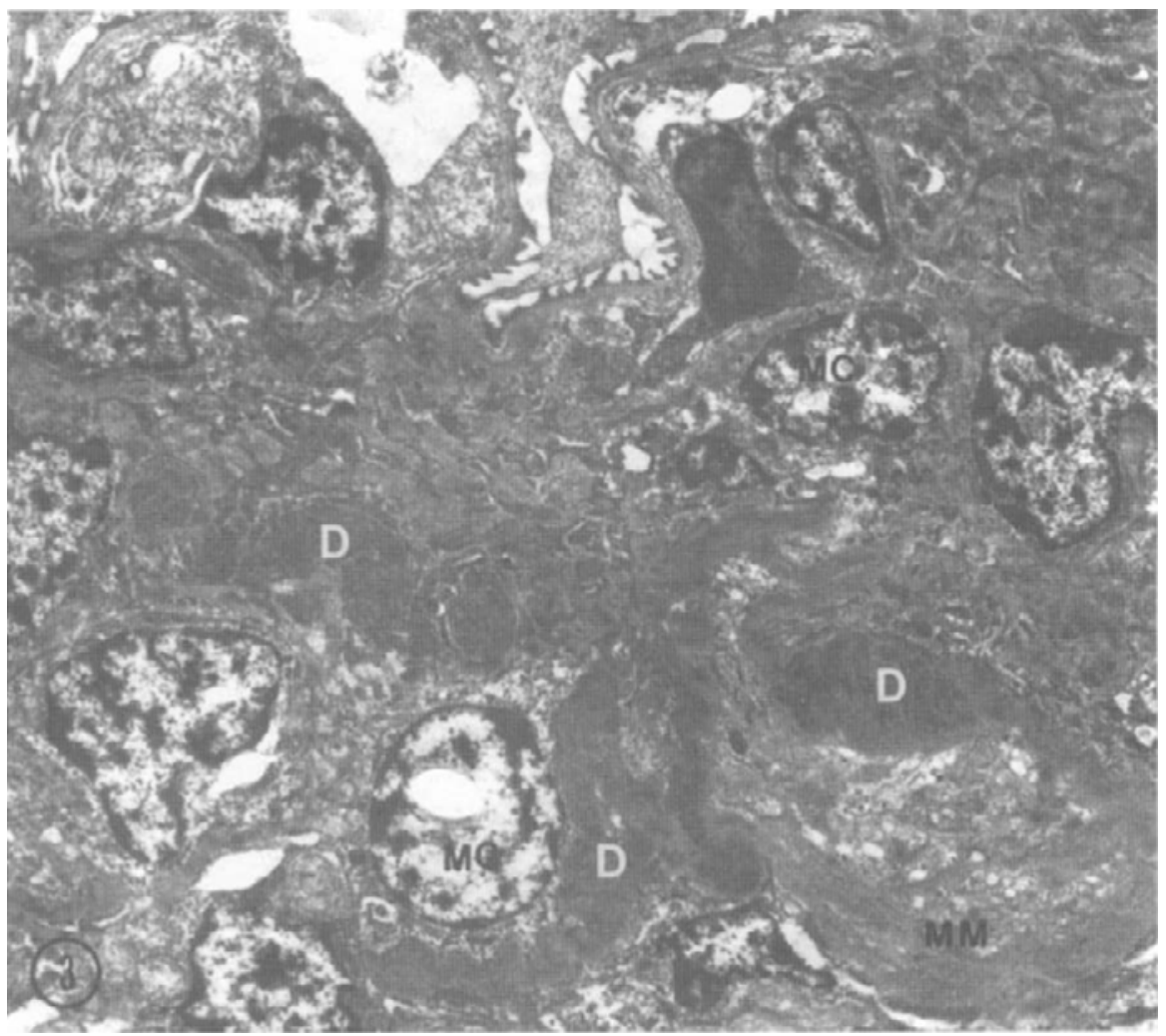

Figure 3. Electron micrograph showing a pronounced increase in mesangialmatrix (MM) and dense deposits (D) in mesangium. MC $=$ nuclei of mesangial cells. $\times 6000$.

by large amounts of basement membrane-like material (Fig. 8).

Control kidneys had glomeruli with normal basement membranes and narrow mesangium and did not have electron dense deposits in these areas.

\section{Immunohistochemistry}

The glomeruli of the affected mink examined had positive focal reactions for IgG. Positive reactions were present as granular deposits in the glomerular basement membrane (Fig. 9). Occasional granular deposits of IgG were visible within the mesangium. However, most glomeruli often showed high intensity of staining in segments of peripheral loops. Staining for IgM was more focal and segmental than for IgG and the positive deposits were present mostly in the peripheral loops and occasionally within the mesangium (Fig. 10). IgA staining was absent in all cases.

Control kidneys did not react for IgA and IgM, but there was a weak segmental reaction for IgG.

\section{Discussion}

This study revealed the presence of mesangial proliferative glomerulonephritis in mink encephalitozoonosis. The fundamental alterations, including the mesangial proliferation and glo- 


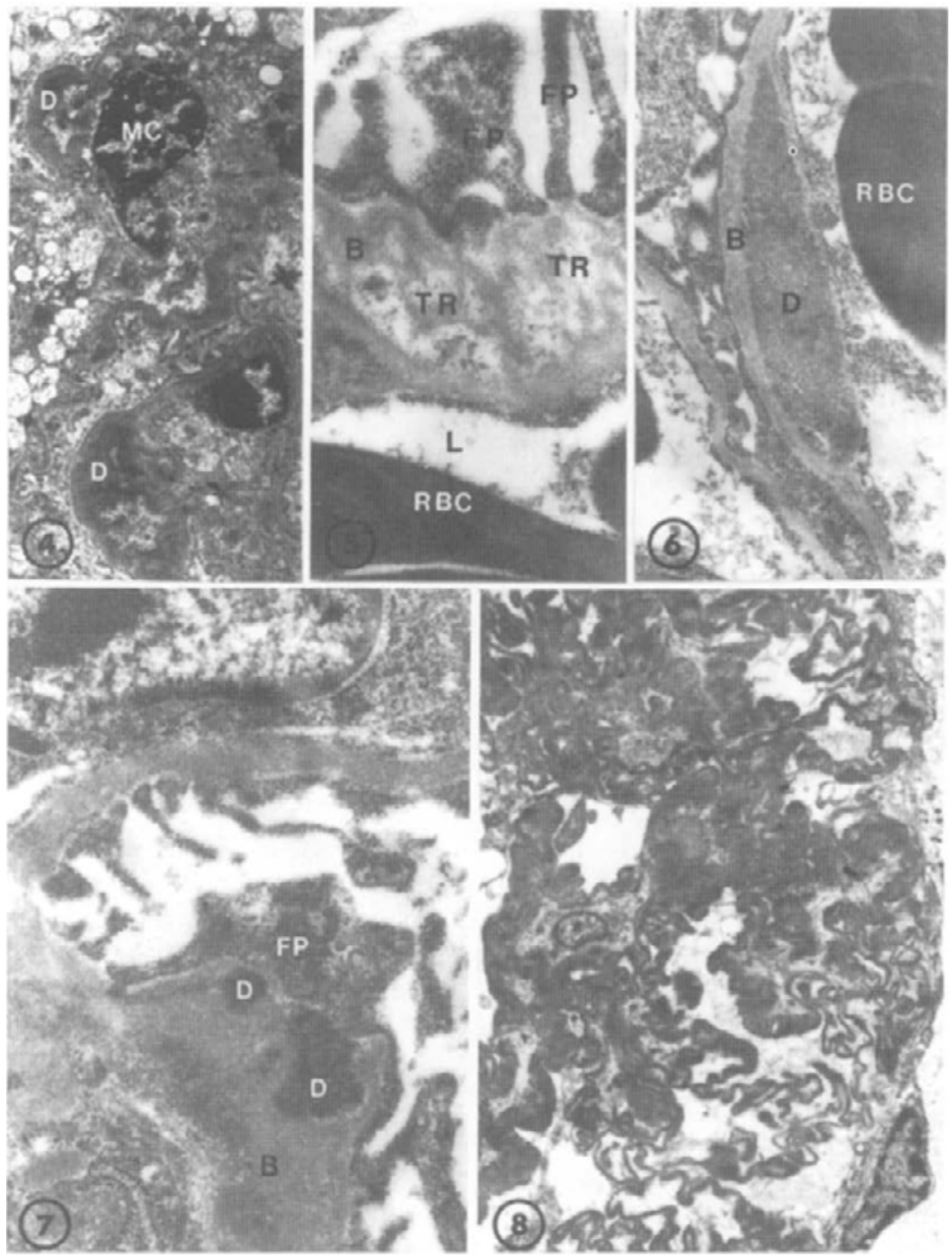

Figure 4. Electron micrograph showing paramesangial electron dense deposits (D). MC = nucleus of mesangial cell. $\times 5000$.

Figure 5. Electron micrograph showing translucent areas (TR) within the segmentally thickened basement membrane (B). $\mathrm{FP}=$ foot cell processes; $\mathrm{L}=$ capillary lumen; $\mathrm{RBC}=$ red blood cell. $\mathrm{x} 21000$.

Figure 6. Electron micrograph showing a subendothelial deposit $(\mathrm{D}) ; \mathrm{B}=$ glomerular basement membrane; $\mathrm{RBC}=$ red blood cell. $\times 12500$.

Figure 7. Electron micrograph showing subepithelial deposits of electron dense material (D) which are present within spike-like projection of basement membrane (B). Note the segmental fusion of foot cell processes $(\mathrm{FP}) . \times 24000$.

Figure 8 . Electron micrograph of a part of a sclerotic glomerulus showing large amounts of basement membranelike material. $\times 5000$. 


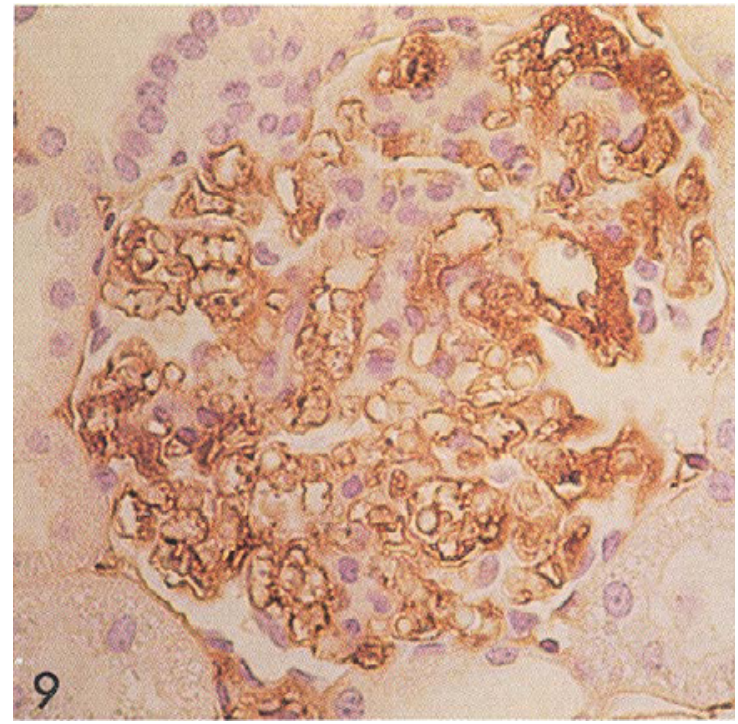

Figure 9. A glomerulus with granular deposits of IgG in glomerular basement membrane. PAP, $\times 260$.

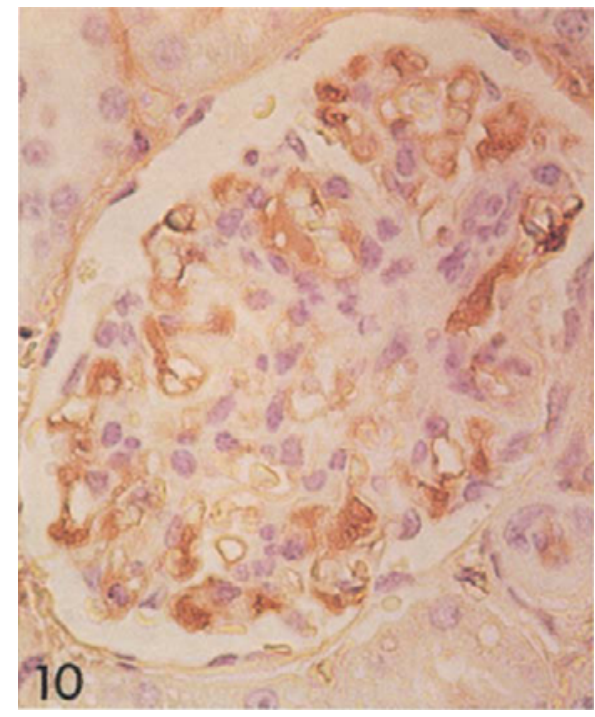

Figure 10. A glomerulus with granular deposits of IgM in the glomerular basement membrane and mesangium. PAP, $\times 260$. merular sclerosis as well as the presence of deposits, resembled morphologically human mesangioproliferative glomerulonephritis (Churg \& Sobin 1982, Kincaid-Smith 1975). Glomerular lesions of encephalitozoonosis have been noted in dogs (McCully et al. 1978) and the mesangial proliferation was similar to that seen in the present material. However, parasitic spores within glomeruli and necrosis of glomeruli as reported in dogs were not observed in our material. In addition, the present study showed small crescents of epithelial and fibrocellular proliferation in some glomeruli. This finding is similar to that in horse with mesangioproliferative glomerulonephritis (Sabnis et al. 1984). The occurrence of crescents indicated the progressive nature of the lesions as their presence in mesangioproliferative glomerulonephritis in man and horse has been associated with a poor prognosis (KincaidSmith 1975, Sabnis et al. 1984).
Electron dense deposits observed with the electron microscope in the glomerular basement membranes and mesangial areas corresponded to those under the light microscope, that stained strongly with PAS reaction. Electron dense deposits were both subendothelial and subepithelial in the capillary walls. The location of deposits may depend on the size of circulating complexes (Bohman et al. 1974).

Mesangioproliferative glomerulonephritis has been encountered in many renal diseases of animals and has been assumed to be induced by immune complexes (Jansen 1988, Müller-Peddinghaus et al. 1980a, Shirota et al. 1986, Slauson \& Lewis 1979). Various forms of glomerulonephritis including mesangial sclerosing, mesangial proliferative and exudative lesions have been observed following Aleutian disease virus infection in mink. The various forms have been correlated to the amount of serum immune complexes (Müller-Peddinghaus et al. 1980b). Our 
study in mink encephalitozoonosis showed that most kidneys were focally positive for IgG and IgM. IgG and IgM granular deposits were located mostly in the glomerular basement membrane and occasionally in the mesangium. Electron dense deposits were often found in the mesangium but could frequently not be detected by PAP staining. A further immunological investigation would be needed.

The finding in this study of sclerotic glomeruli with increased matrix and wrinkled or obliterated glomerular capillaries is indicative of an advanced mesangial proliferative glomerulonephritis. The increased accumulation of macromolecular substances including immunoglobulins or other plasma proteins may activate mesangial cells to proliferate and produce additional matrix which may eventually lead to glomerulosclerosis (Kashgarian 1985).

The extraglomerular involvement (interstitial nephritis and vasculitis) observed in this material was similar to that reported in dog, blue fox and rabbit (Botha et al. 1986, Nordstoga 1972, Sanford 1987), except for the finding of multiple renal cysts which are discussed in a preceding paper (Zhou et al. 1992). The present study would suggest that the progress of glomerular lesions was correlated to that of the interstitial nephritis and vasculitis. The simultaneous occurrence of lesions in both glomerulus and interstitium of affected kidneys has also been noted in dog and horse (Krohn et al. 1973, McCausland \& Milestone 1976). It would appear that glomerular lesions should be paid more attention in association with interstitial nephritis also in other animal species.

\section{Acknowledgements}

The authors thank Dr. Bent Aasted, Royal Veterinary and Agricultural University, Copenhagen, Denmark, for providing the rabbit anti-mink sera and Dr. Johan Høgset Jansen for valuable suggestions. We thank Birgit Røe, Ingjerd Andersen and Anne Kristine Fevang for skilled technical assistance.

\section{References}

Bjerkås I: Brain and spinal cord lesions in encephalitozoonosis in mink. Acta vet. scand. 1990, 31, 423432.

Bjerkås I, Nordstoga K, Nicolaissen B, Loftsgaard G: Encephalitozoonosis in mink. 4th Int. Sci. Congr. Fur Anim. Product. Toronto, Canada and Wisconsin, USA, 1988 (poster).

Bohman S-O, Olsen S, Petersen VP: Glomerular ultrastructure in extracapillary glomerulonephritis. Acta pathol. microbiol. scand. Sect. A, Suppl. 1974, 249, 29-54.

Botha WS, Van Dellen AF, Stewart CG: Canine encephalitozoonosis in South Africa. J.S. Afr. vet. med. Ass. 1979, 50, 135-144.

Botha WS, Stewart CG, Van Dellen AF: Observations on the pathology of experimental encephalitozoonosis in dogs. J.S. Afr. vet. med. Ass. 1986, 57, 17-24.

Cho HJ, Greenfield J: Eradication of Aleutian disease of mink by eliminating positive counterimmunoelectrophoresis test reactors. J. clin. Microbiol. 1978, 7, 18-22.

Churg J, Sobin LH: Renal Disease - Classification and Atlas of Glomerular Diseases. Igaku-Shoin, TokyoNew York 1982.

Dore M, Morin M, Gagnon H: Proliferative glomerulonephritis leading to nephrotic syndrome in a cow. Can. vet. J. 1987, 28, 40-41.

Jansen JH: Renal lesions in swine. Thesis., Oslo 1988 pp. $45-73$.

Kashgarian M: Editorial : Mesangium and glomerular disease. Lab. Invest. 1985, 52, 569-571.

Kincaid-Smith P: The Kidney - A Clinico-pathological Study. Blackwell Scientific Publications, Osney Mead, Oxford 1975, pp. 50-65.

Krohn K, Jokelainen PT, Sandholm M: Light and electron microscopic observations on glomerular changes in canine interstitial nephritis. Acta pathol. microbiol. scand. Section A 1973, 81, 461-473.

McCausland IP, Milestone BA: Diffuse mesangioproliferative glomerulonephritis in a horse. N. Z. vet. J. 1976, 24, 241-259.

McCully RM, Van Dellen AF, Basson PA, Lawrence J: Observations on the pathology of canine microsporidiosis. Onderstepoort J. vet. Res. 1978, 45, 75-92.

Müller-Peddinghaus $R$, Kalden JR, Schawbedissen $H M$ zu., Trautwein $G$, Ueberschär S: Immune complex glomerulonephritis of mink with Aleutian disease. Contr. Nephrol. 1980a, 19, 101-103.

Müller-Peddinghaus $R$, Kalden JR, Schawbedissen HM zu., Trautwein G, Ueberschär S: Correlation 
of various forms of glomerulonephritis to the amount of serum immune complexes in mink with experimental Aleutian disease. Vet. Pathol. 1980b, $17,653$.

Nordstoga $K$ : Nosematosis in blue foxes. Nord. Vet.Med. 1972, 24, 21-24.

Plowright W: An encephalitis-nephritis syndrome in the dog probably due to congenital encephalitozoon infection. J. comp. Pathol. 1952, 62, 83-93.

Portis JL, Coe JE: Deposition of IgA in renal glomeruli of mink affected with Aleutian disease. Amer. J. Pathol. 1979, 96, 227-236.

Sabnis SG, Gunson DE, Antonovych TT: Some unusual features of mesangioproliferative glomerulonephritis in horses. Vet. Pathol. 1984, 21, 574-581.

Sanford SE: Encephalitozoonosis in a pet rabbit. Can. vet. J. 1987, 28, 417.

Shadduck JA, Pakes SP: Encephalitozoonosis (nosematosis) and toxoplasmosis. Amer. J. Pathol. 1971, 64, 657-672.

Shirota K, Yoyama R, Nomura Y: Glomerulopathy in swine: microscopic lesions and IgG or C3 deposition in 100 pigs. Jap. J. vet. Sci. 1986, 48, 15-22.

Slauson DO, Russell SW, Schechter RD: Naturally occurring immunecomplex glomerulonephritis in the cat. J. Pathol. 1971, 103, 131-133.

Slauson DO, Lewis RM: Comparative pathology of glomerulonephritis in animals. Vet. Pathol. 1979, 16, 135164.

Testoni FJ: Enzootic renal nosematosis in laboratory rabbits. Aust. vet. J. 1974, 50, 159-163.

Van Rensburg IBJ, Du Plessis JL: Nosematosis in a cat: a case report. J. S. Afr. vet. med. Ass. 1971, 42, 327331.
Waller T: The india-ink immunoreaction: a method for the rapid diagnosis of encephalitozoonosis. Lab. Anim. 1977, 11, 93-97.

Wilson JM: The biology of Encephalitozoon cuniculi. Med. Biol. 1979, 57, 84-101.

Zhou Z-y, Nordstoga K, Bjerkås I: Extraglomerular lesions in kidneys of mink with encephalitozoonosis. Acta vet. scand. 1992, 33, 33-41.

\section{Sammendrag \\ Mesangioproliferativ glomerulonefritt hos mink ved encephalitozoonose}

Glomerulære forandringer hos 6 mink med encephalitozoonose ble studert lysmikroskopisk, elektronmikroskopisk og ved immunhistokjemiske metoder. Dyra var frie for plasmacytose ("agartest"). I de fleste glomeruli forelå det mesangioproliferativ glomerulonefritt med forøkelse av mesangiale celler og matriks. Enkelte glomeruli var sklerotiserte. I tillegg viste elektronmikroskopiske studier segmentalt fortykket eller foldet basalmembran og elektrontette avleiringer i basalmembranen og i mesangiet. Peroksydaseantiperoksydase immunhistokjemi viste avleiring av granulært IgG og IgM positivt materiale i basalmembranen og av og til i mesangiet. Ekstraglomerulære forandringer inkluderte acellulære cylindre i tubuli både $\mathrm{i}$ bark- og margsonen, interstitielle betennelsesforandringer, vaskulitt og cyster utviklet fra avsnørte tubuli.

(Received September 17, 1992; accepted September 30, 1992).

Reprints may be requested from: K. Nordstoga, Department of Pathology, Norwegian College of Veterinary Medicine, P.O. Box 8146, Dep., N-0033 Oslo 1, Norway. 